\title{
THE LANGUAGE CHOICE AS A REFLECTION OF ISLAMIC COMMUNICATION IN THE QURAN-JAPANESE TRANSLATION
}

\author{
Ely Triasih Rahayu', Ahmad Fauzan² \\ 1,2 Jenderal Soedirman University (UNSOED), Indonesia \\ Jl. Dr. Suparno, Purwokerto, 53123 Indonesia \\ E-mail: 'ely.rahayu@unsoed.ac.id, 2fauzanahmado83@gmail.com
}

\begin{abstract}
Ittishâl in Arabic language means message connectivity within a communication process. In Islam, a communication process requires the precision of language users in choosing a language. Language choice in Islamic communication aims at maintaining a positive relationship among humans (hablumminannâs), and humans' sincere love to God (hablumminallâh). This qualitative research which data source is from surah AnNisâ' discusses how the Quran translated into Japanese language distinguishes language choices for humans (as God Servants) and those intended to praise God. There are noun word choices for God which are initiated with the kanji marker go/o (御) and not found in those referring to humans. Furthermore, there are respectful verbs (songkeigo) to praise the God's actions, yet not for humans'. These language choice's differences are intended to educate humans not to be arrogant or to always be humble because only God is the Sublime. The other objective is as the communication guidance in Islam, especially in performing prayers to always use polite languages to praise God that a sincere love will be created from the servants to the God.
\end{abstract}

Keywords: language choice; Islamic communication; Japanese language; surah An-Nisâ’.

\begin{abstract}
Abstrak: Ittishâl dalam bahasa Arab berarti konektivitas pesan dalam proses komunikasi. Dalam Islam, proses komunikasi membutuhkan ketepatan pengguna bahasa dalam memilih bahasa. Pilihan bahasa dalam komunikasi Islam bertujuan mempertahankan hubungan yang baik antara manusia (hablumminannâs), dan cinta manusia yang tulus kepada Allah (hablumminallâh). Penelitian kualitatif yang sumber datanya berasal dari surah Al-Nisâ', membahas bagaimana Alquran yang diterjemahkan ke dalam bahasa Jepang membedakan pilihan bahasa bagi manusia (sebagai Hamba Tuhan) dan yang dimaksudkan untuk memuji Tuhan. Tidak ada pilihan kata untuk Tuhan yang dimulai dengan penanda kanji go / o (御) dan tidak ditemukan pada mereka yang merujuk pada manusia. Selain itu, ada kata kerja penuh hormat (songkeigo) untuk memuji tindakan Tuhan, namun tidak untuk manusia. Perbedaan pilihan bahasa ini dimaksudkan untuk mendidik manusia untuk tidak menjadi sombong atau untuk selalu rendah hati karena hanya Tuhan yang Mahakuasa. Tujuan lainnya adalah sebagai pedoman komunikasi dalam Islam, terutama dalam melakukan doa untuk selalu menggunakan bahasa yang sopan untuk memuji Tuhan bahwa cinta yang tulus akan diciptakan dari para hamba kepada Tuhan.
\end{abstract}

Kata kunci: pilihan bahasa; komunikasi Islam; bahasa Jepang; surah An-Nisa'.

\section{Introduction}

As one of the greatest religions in the world, Islam teaches balanced communication between hablumminallâh and hablumminannâs. Hablumminallâh and hablumminannâs are human's two-way communication. Hablumminallâh is human's directional communication with Allah, while hablumminannâs is human's directional communication with fellow human. Communication in Arabic is tawashul. Tawashul is derived from the word "washala" which means "delivered".
Therefore, tawashul is a process of information exchange conducted by two parties, so that the message delivered may be understood by the two communicating parties. Another term in Arabic to refer the term communication is ittishâl, which emphasizes more on the meaning of message connectivity. In ittishâl, when the message sent by a communication is delivered and conveyed to a communicant, that is a communication and there is no necessarily a feedback.

Islam teaches polite communication both 
communication of humans and communication to Allah. To communicate is principally to outline a sentence to be delivered to others. Human must smartly select their language for communication to be well delivered. An individual's politeness may be observed from his/her delivery of language. Japanese is an example of language with selection of language in expressing honorific language. Japanese consists of speech levels. Speech level is variation of language of which differences are determined by speaker's assumption of his/her relationship with listener. ${ }^{1}$ Relationship may be intimate, moderate, distant, ascending, flat, and descending. Intimate, moderate, and flat relationships may be aligned to horizontal dimension ${ }^{2}$. The term horizontal dimension is called symmetric relationship and asymmetric relationship, including distant, ascending, and descending relationships. Human relationship with the Creator is vertical, in which Allah is placed at the highest position among anything. ${ }^{3}$

Japanese and Arabic language have similarities in mentioning the honorific levels to the interlocutors based on the social status/level in the society. Arabic language considers that social levels are based on aristocracy, nobility, and descendent, such as Syekh, Sayyîd, to mention the aristocracy, Habîb to mention the descendent of our prophet Muhammad, PBUH, Wan to mention the equal social status/level, and Masâkîn (poor people or dhu'afâ') to mention the low social level. ${ }^{4}$

The Quran translation into Japanese by Mita $^{5}$ was just issued in 1972. Previously, there

${ }^{1}$ Maryono Dwiraharjo, "Fungsi dan Bentuk Krama Dalam Masyarakat Tutur Jawa Studi Kasus di Kotamadya Surakarta (Krama Language Functions and Forms in Javanese language Use: A Case Study in Surakarta Municipality)", Dissertation, (Yogyakarta:UGM, 1997)

2 Suwito, "Berbahasa dalam Situasi Diglosik: Kajian tentang Pemilihan dan Pemilahan Bahasa dalam Masyarakat Tutur Jawa di Tiga Kelurahan Kotamadya Surakarta (Using Language in Diglossic Situations : A study on Language Selections in Javanese Language Use)", Dissertation, (Jakarta: UI, 1987), p.124

${ }^{3}$ Bambang Kaswanti Purwo, "Tingkat Tutur Bahasa Jawa: Tata BahasadanPragmatik (Javanese Language Use Levels: Language Patterns and Pragmatics)", Paper in Congress of Javanese Language I, (Semarang, 1991), p.5

4 Natalie Kasheh, Hadrami Awakening: Kebangkitan Hadrami di Indonesia ([Hadrami A wakiening in Indonesia), (Jakarta: Akbar Media Eka Sarana, 2007), p.23

5 Umar Mita is the most prominent name in the Japanese history of Islam. He was born on December 19, 1892 in Chofu City, Yamahguchi, Japan. He changed his given name from were translations of Kitabullâh issued in 1920, 1937, and 1950. However, all of the translations were composed by non-Muslim. It is Mita who was the first Muslim to translate the Quran into Japanese. Mita finished his translation in 1968. In 1970, he proposed his revised translation to the Muslim World League based in Mecca. Six months after the revision, the Quran translation was printed in Hiroshima. On June 10, 1972, the printing was finished and the translation started to be published. Until publication, Mita spent no short time of 12 years.

The Quran in Japanese translation employs language choice which distinguishes between languages addressed to Allah and that addressed to human. Language choice in Quran in Japanese translation is based on the language speech level. Japanese language speech level consists of two, namely: futsuukei 'common language' and keigo 'honorific language'. Keigo consists of sonkeigo 'language to elevate others', teineigo 'polite language'. This speech level division may be observed with difference in vocabularies. The lexical dimension shows that all verbs of dictionary form (listed in Japanese dictionary) have futsuukei mark in the end of sentence. These vocabularies of futsuukei verbs are unlimited in the number, while sonkeigo and kenjougo have lexical marks in limited number. ${ }^{6}$

The morphological dimension is reflected in the sentence pattern to form the language speech level. Sonkeigo has morphological marker with a

Ryoizhi Mita to Umar Mita after embracing Islam. Umar Mita's family were from among Samurai. Like other Japanese people, Mita's family were Buddhists. From childhood to adulthood, Mita had no idea of what Islam is. He had never met a Muslim. The dawn of Islamic missionary work in the Land of the Rising Sun was a bit late compared to its surrounding countries. He just knew Islam when he studied in China after graduation from Yamaguchi Commercial College. During his study in China, he often interacted with Chinese Muslims. Mita was then interested in Islam. He had the chance to write about Islam in China in a Japanese magazine, Toa KeizaiKenkyu (Far -East Economic Research Journal) in 1920. It seems that he liked Muslim's way of life. Mita then learned about Islam from Haji Omer Yamaoka, the first Japanese Muslim who went to Mecca for hajj. After much understanding of Islam, Mita declared shahada in 1941 while he was 49 years old. He was then determined to be a Muslim kaffa. See, Umar Mita, Sei Kuruaan, (Tokyo: Nihon Muslim Kyoukai, 2012), p. 25

${ }^{6}$ Ely Triasih Rahayu. Sistem dan Fungsi Tingkat Tutur Bahasa Jepang dalam Domain Perkantoran (Japanese Language Use Systems and Functions in Office Domains), Dissertation, (Universitas Sebelas Maret, 2013), p.3 
pattern of olgo Vrenyoukeininaru, -(ra)reru, gonasaru. ${ }^{7}$ Kenjougo has a pattern of o/go-shimasul moushiagemasu. ${ }^{8}$ The difference in the use of vocabularies in the Japanese translation the Quran teaches mukmin that how to communicate with fellow human and with his/her Creator. This research will study mukmin how to communicate with Allah, so that the effort to get close to Allah may be shown with language choice showing humility before the God.

Communication does not only focus on what to be conveyed but communication must also pay attention to the situation and context. The context here is communication in Islam. As science, Islamic communication has the main references as the life guidelines for mukmin, which are the Quran and Hadith of Prophet Muhammad, PBUH. These two main sources present guidelines on Islamic communication. Learning Islamic communication imposes various advantages, which are: ${ }^{9}$ ) Guide Muslims, specifically, and humans, generally, to communicate with the Creator; 2) Guide Muslims to communicate with themselves; 3) Guide Muslims to communicate fellow humans based on Islamic teaching.

The Islamic communication learnt will pay attention to how language is used to address to Allah and His creations called muslimah or Muslim women. The relevant surah with discussion on women's position in Islam is surah Al- Nisâ'. It is called Al- Nisâ' (women) since laws related to women are mentioned more in this surah than in other surahs (Mahasinut Ta'wîl, 3/6).

Surah An-Nisâ' is defined as Women, classified into Medinan and has 176 verses. The fourth surah is included in the fourth, fifth and sixth juz. An-Nisâ' is the second longest surah after Al-Baqarah. It is named An-Nisâ' since this surah has many things discussed related to women. Other surahs also discuss much about women, such as surah At-Thalâq and surah Maryam. Surah An-Nisa is also called surah An- Nisâ' Al-Kubrâ (Surah greater An- Nisâ') and surah An-Nisa Asshughrâ (Surah lesser An- Nisâ'). ${ }^{10}$

\footnotetext{
${ }^{7}$ Yasuto Kikuchi, Keigo Nyuumon (Tokyo: Maruzen, 1997)

${ }^{8}$ Hiroyuki Kaneko, Nihongo Keigo Toreeningu, (Tokyo: PT Ask, 2004)

9 Harjani Hefni, Komunikasi Islam, (Jakarta: Prenada Media, 2017)

${ }^{10}$ Rasm Usmani, Al-Qur'an Tafsir Perkata [Quran and its Interpretations Say], (Bandung: Cordoba, 2018)
}

Historically, surah An-Nisâ' refers to the life of women during the Prophet era, where women were treated badly by men that they were subordinated by men. More precisely, it discusses how jahiliyah era treated women, norms in interaction with wife, individual's right and obligations, violence, oppression, and forced subjection over women. One of the stories in surah An-Nisa refers to the story of prophet Musa AS, where there was a women named Siti Asiyah binti Muzahim, a wife of King Firaun, who was renowned for his cruelty.

Siti Asiyah, renowned for her strong faith, was of Israelites, descendants of the Prophets. Siti Asiyah was a figure of patience, obedience and honor. She was good in character and physical beauty, attracting King Firaun to take her as his wife. In short, when she stood to take care of Prophet Musa AS and supported any of Prophet Musa's actions instead of those of her own husband and rejected his husband's self-proclamation of divinity, then SitiAsiyah was tortured by Firaun, tied on her legs and arms, and made lying on hot ground, with her face facing the sun. Moreover, Firaun instructed his Executioner to put a big piece of rock on her. ${ }^{11}$

Under such torture, Siti Asiyah did not feel tormented but felt of being in paradise, since Allah had shown her Paradise and her sour had left the body, thus it is appropriate that Allah had guaranteed her paradise. In a hadith narrated by Imam Ahmad, Prophet Muhammad also praised Siti Asiyah as he said: The best women in paradise are Khadijah binti Khuwalid, Fatimah binti Muhammad, Maryam binti Imran and Siti Asiyah binti Muzahim. In the story, Allah praises women with high faith and taqwa highly. There is no reason to determine who deserves, who has merit or who is strong to obtain high position, but faith and taqwa as the main reference ahead of expertise.

In the research context, the researcher conducts analysis with a review perspective. This is sociolinguistic perspective, aiming at analyzing appropriate verbs, vocabularies, word speech level and intention in positioning relationship with Allah, humans and Allah's creations.

1 Joy Amarta, Kisah Teladan Perjuangan 25 Nabi dan Rasul [The Inspiring Stories of 25 Prophets and Messengers], (Yogyakarta: Cheklist, 2019) 


\section{Method}

This is a qualitative research. Qualitative research is a process to analyze data descriptively in collecting information or data and investigate the collected data, thus the research discussion will be understood comprehensively. ${ }^{2}$ The research's analysis object is the Quran surah An-Nisâ' which is translated into Japanese through language selection containing Islamic communication, to be analyzed by employing the existing theory.

The purpose of data analysis (the Quran translation) is to understand the meaning of the Quran, especially in the translation of women in surah An-Nisâ', of how women are positioned in such verse, kind of concerned women, and the essence of women. All of which may be realized through appropriate language choice in Japanese translation. In addition, it is also about how to use language choice to have relationship between the Creator, humans and all creations through appropriate Japanese language choice. In language choice, there are two parts to be analyzed, which are speech level and appropriate verb or noun choice pursuant to Japanese language principles without altering the meaning of the Quran.

The data analysis process is a process of effort to process the data into new information so that the characteristics of data will be more understandable and useful to be solution to a problem. ${ }^{13}$ This data analysis starts with collection of sources of information related to the research, such as holy Quran, books (theory, research methodology and guidelines on Japanese language) and reference via website on theories on sociolinguistic, communication and cultural reviews, as well as sources related to required information. Further phase is to summarize, select subject matter and find formulation of the problem pattern. It is also likely that the researcher also uses secondary data obtained from literary study and documentation as supporting data.

12 Lexy J Moleong, Metodologi Penelitian Kualitatif [Qualitative Research Methodology], (Bandung: PT Remaja Rosdakarya, 2001).

${ }^{13}$ Sugiyono, Metodologi Penelitian Kualitaif, Kuantitatif dan Kombinasi [Qualitative, Quantitative, and Mixed Research Methodology], (Bandung: Alfabeta, 2016)
The next phase is to analyze by presenting data in the form of description of understanding of the text of the Quran based on Japanese translation in the form of speech level, verb and intention addressed with appropriate language choice to be a reflection of Islamic communication. The last step of analysis is to make a conclusion in the form of new finding descriptively.

\section{Language Choice}

The science related to language choice in the society is sociolinguistics. Sociolinguistics is "....the study of language as part of culture and society". Language study serves as part of culture and society (Language is culture) ${ }^{14}$. Similarly, Mansoer Pateda (1991) states that sociolinguistics is a branch of linguistics to study language and language use in cultural context, from language choice, language speech level and meaning context in society's culture. Sociolinguistics may be concluded as a study related to linguistic issues and their relationship with social, situational and cultural aspects.

Pursuant to the research title "Pemilihan Bahasa sebagai Cerminan Komunikasi Islam dalam Al-Qur'an Terjemahan Bahasa Jepang", the language in the Quran is chosen carefully for correct understanding, so as not to lead to the society's misunderstanding in is implementation. There are possible conflicts, controversies, and misappropriations which start from false understanding of the guidelines (the holy book) through teachers whom they learn from. Therefore, it is important to conduct this research in order to add one's insight in daily implementation pursuant to the meaning contained in the Quran, in the form of hablumminallâh and hablumminannâs. For further study, the researcher reviews this research through linguistic theories along with their terms.

An individual who masters two or more languages will place him/herself at the interlocutor's position. Social and cultural factors are the basis of language choice. The factors of language choice identification in social interaction are: first, situational background (time and place); second, participant in interaction; third, topic of conversation; and fourth, function of interaction.

14 J.B Pride and J Holmes.Sociolinguistics. England: Penguin, 1972 
It is described above that keigo' honorific language' is highly influenced by five aspects, namely; ningenkankei 'relationship between participants', ba'place', ishiki 'awareness', naiyou 'content' and keishiki'form'. According to Kabaya, the most important aspect in speech is ningenkankei 'relationship between participants' and ba 'place' or bamen 'background'. ${ }^{15}$ However, with regard to language choice in the Quran translation, a translator must be aware of the background (writing time and writing place) and exact situation in the dynamic language development. He/she should then know the target readers (by age) and appropriate position and layout of words and determine the correct topic pursuant to interesting issues discussed and advantages to the society, for example, gender issue in surah An-Nisâ'. Lastly, the translator is expected to be able to choose informative and familiar language to the society.

The explanation of the factors above shows that the studies on language choice so far show that the position factor is more important the any other factors. The concerned position is the meaning of the Quran. The language choice in the translation of the Quran surah An-Nisâ' into Japanese must be adapted to Japanese language structure principle while maintaining the meaning of the Quran between one language and the other language.

Essentially, speech level may be adapted to language choice to be translated, but the content and meaning in the Quran cannot be altered, because the Quran is a higher position than other factors or linguistic structure issues (grammar). The reason is that because various languages have different speech level and different linguistic structure, but they have the same definition. The main thing of note is understanding the appropriate position of the Quran translation as the reflection of Islamic communication which is taken as the main guidelines, thus language speech level knowledge as the appropriate basis of communication science is necessary. Language speech level in communication process should note who, says what, to whom and with what

${ }^{15}$ Kabaya, Hiroshi. et al. Keigo Hyougen.Tokyo:Taishuukan, 2009. Also See, Ely Triasih Rahayu, "Sonkeigo Expressions in Japanese Translation of the Quran." MADANIA: JURNAL KAJIAN KEISLAMAN, vol. 21.no. 2 (2017) pp. 145-156. effect. ${ }^{16}$ Based on the theory, speech level may be easily understood by readers, thus they will be able to interpret who we are, to whom it is meant and the consequence, all of which are based on hablumminallâh and hablumminannâs.

Similarly, analysis on the Quran translation in local language (Indonesian language) and international language (Japanese language) states that they have language choice pursuant to the interlocutor or speech level. In Indonesian language, there are the most polite form "saudara", moderate form "anda" and rude form "kau, kamu". On the other hand, Japanese language, for example, has two speech levels: futsungo (common language) and keigo (honorific language). Basically, discussion on Japanese language in the Quran includes the teaching of how human communicates with Allah and human communicates with fellow human. Islamic communication which may be reviewed in the language choice in the Quran includes some existing discussions in the society and universe. ${ }^{17}$ One of the things still discussed in the society until now is gender.

\section{Language Choice Review Approach}

Review on language choice is conducted based on three approaches, which are sociological, social and anthropological approaches..$^{18}$ Sociological approach is related to domain analysis. Domain is theoretical concept which marks interactional situation based on the same experience, such as family, religion, relative, and occupation. For example, when a speaker is talking at home to a family member about a topic, the speaker is within family domain.

Psychological approach is related to be more human psychology than to wider societal category. This approach leads more to individual interest covering personal needs, background situation and temporal situation. The language choice also highly depends on personal situation and certain situation. Similarly to anthropological approach, it is related that how to a speaker

\footnotetext{
${ }^{16}$ Daryanto, TeoriKomunikasi [Communication Theories], (Malang: GunungSamudera, 2014)

${ }^{17}$ Harjani Hefni, Komunikasi Islam [Islamic Communication], (Jakarta: Kharisma Putra Utama, 2017)

${ }^{18} \mathrm{R}$ Fashold, The Sociolinguistics of Society, (Oxford: Basil Blackwell, 1984)
} 
connects with society structure. The difference is that while social psychological approach takes perspective of speaker's psychological needs, anthropological approach is regarding how an individual chooses language to express cultural values.

Of the three approaches, sociological and anthropological approaches are more appropriate to this research since they are based on domain (interaction of the same experience of religious knowledge) and anthropology (social and culture). All of them are based on descriptive data of text observation (the Quran) in Japanese translation. Anthropological observation method may present perspective of explanation of the language choice based on the meaning in the Quran reflecting Islamic communication in the Japanese translation.

\section{Communication in Islam}

The communication in the Quran translation must have the three main principles for the translator and readers, ${ }^{19}$ among other, understand who is addressed to, what is meant and how the implementation in the society is, which may be understood when the translation uses correct language choice pursuant to the principles of target language (Japanese). As in Lasswell's communication theory, communication with whom (interlocutor must be identified) - Allah must use the highest level of language, full of humility. For example, almost all surah of the Quran uses Bismillâhirrahmânirrahîm, aiming at calling us to prioritize mentioning the name of Allah with the highest possible praise. There is only one surah, At-Taubah, that does not use the words since this surah is assumed to explain war. This is as if there is mutual necessity, since it starts by praising Allah.

Allah's need does not mean that He needs humans which may be beneficial to Him, but it needs to be confirmed here that Allah does not need anything beneficial to Him (like humans).

We, His creations, absolutely need Allah

19 Armawati Arbi, Komunikasi Intrapribadi "Integrasi Komunikasi Spiritual, Komunikasi Islam dan Komunikasi Lingkungan [The Integration of Spiritual, Islamic and Environmental Communication], (Jakarta: Kencana, 2019) in the best possible methods so that we may benefit from Allah by praying. Allah only calls us to worship Him with sincerity, integrity and intention. In order to achieve it, we need to continuously improve our worship quality by praising, glorifying and being humble before Allah through verses of the Quran. Therefore, it requires the best word speech level for Allah according to such methods (Islamic communication), and good word speech level for humans and protect His creations. Through language choice, we may expect something, give something and implement something, so that our lives will be taken care of and protected by Allah.

The principle of Islamic communication is communication built on Islamic principles with the spirit of peace, hospitality and safety. ${ }^{20}$ Islamic communication has the main references which are the life guidelines for Muslims, namely the Quran and Hadith. These two main sources are the basis of characteristics of Islamic communication. Meanwhile, an effective communication in Islamic perspective is necessary in the society in order to maintain peace, conformity and harmony both verbally and non-verbally. According to Hefni, some forms of verbal communication in Islamic communication are: low intonation, appropriate wording (to whom, what is talked about and what is situation), gentle voice, understanding message receiver's mental state, avoiding domination of conversation and avoiding reproach in conversation. Meanwhile, nonverbal communication includes some physical gestures, such as: happy and cheerful, the best possible eye contact with humility, and using polite hand movement. The main purposes of Islamic communication are to give information as best as possible, give assurance, give reminder in the sense of preach, motivate, have social sense, give guidance, give spiritual satisfaction and entertain.

The review in this research is based on the principles of Islamic communication through Japanese translation by Japanese grammar, speech level, and function of words and meanings contained in surah An-Nisâ'.

\footnotetext{
${ }^{20}$ Harjani Hefni, Komunikasi Islam..., 2017.
} 


\section{Discussion}

As discussed in the previous explanation, the research's focus of analysis is on surah An-Nisâ'. The surah tells stories of the life of women, in which the review uses correct language choice pursuant to Japanese language speech level principles as a reflection of Islamic communication. The analysis will be distinguished between language choice for women and language choice for Allah. Surah An- Nisâ' is not entirely analyzed, but a sampling method is employed instead. The data analysis which is in the form of Japanese translation will start with Japanese letters (kana and kanji), which will be transcribed using romaji (Latin) letters and translated into English.

Surah An- Nisâ' starts with a verse to exalt women by indicating creation of women from men's rib. The word containing the meaning of rib is expressed as 魂 tamashii, which means soul, such as in the translation of surah An-Nisâ' verse 1 below.

1）かれはひとつの魂からあなたがたを創り、 またその魂から、配偶者を創り、両人から 無数の男と女を増やし広められた方であら れる。

Kare wa hitotsu no tamashi kara anatagata o tsukuri,mata sono tamashī karahaigūsha o tsukuri, ryōninkaramusū no otoko to onna o fuyashihiromerareta hō de arareru.

'O mankind, fear your Lord, who created you from one soul and created from it its mate and dispersed from both of them many men and women.' (An- Nisâ' [4]:1)

This verse states that Allah created its mate in one soul. The language choice for the word soul in the Quran Japanese translation uses the word tamashī (魂). Qatadah and Mujahid Rahimahumallah state that what is meant by tamashiiis one soul between Prophet Adam and his mate, Eve. Based on this verse, it is interpreted that Eve was created from Adam's rib. ${ }^{21}$ Women were actually created just like the characteristics of rib. They were bent just like rib since they were derived from rib. When a husband wants

${ }^{21}$ Hadiths of creation of women from rib are available in some books of hadith, such as in the book of Musnad al-Humaidi, al-Mustakhraj ‘ala Shahih Muslim, Shahih Ibnu Hibban, al-Mu’jam al-Ausath by al-Thabari, al-Mustadrak 'ala al-Shahihain by al-Hakim, Sunan al-Darimi, and al-Sunan al-Kubra by al-Nasai. to make them straight with no bend at all, it will certainly lead to dispute and separation. This means breaking it. However, if the husband is patient with wife's bad condition, weak reasoning and her bend, their togetherness will last forever.

The word tamashi in the data is a neutral noun, which means that there is no honorific marker addressed to the owners of soul, Adam and Eve. Islamic communication in the Quran in Japanese translation clearly shows difference in the nouns addressed to human and Allah. In the next part of surah An- Nisâ' verse 1 above, there is a noun of sonkeigo form (respectful language) as an honorific expression to Allah.

\section{2）かれの御名においてお互いに頼みごとをす} る御方であられる。

Kare no gyomei ni oite otagai ni tanomigoto o suru okata de arareru.

'And fear Allah, through whom you ask one another, and the wombs.' (An- Nisâ' [4]:1)

The word gyomei is translated into a name. The name in this verse refers to the name of Allah. This word in the Quran Japanese translation is specially written with kanji marker go/o(御). This kanji in Japanese serves as a honorific marker for noun that follows. Another example of the use of this kanji honorific marker is gokazoku (ご家族) 'family’, gosetsumei (ご説明) ‘explanation', and okarada (お身体) 'body'. These words cannot be used for oneself, but for others as a form of honorific. In this surah An-Nisa verse 1, Kanji 御 is followed by kanji 名 (mei). The word mei is the abbreviated form of the word shimei (氏名). In the word gyomei (御名), kanji 御 is not read go but gyo instead, thus the word gyomei is used to refer to the meaning of the name of Allah.

In the verse, there is also a honorific for Allah with marker 御 in the word 御方, which is read okata, the honorific form of $\curlywedge$ (hito) 'human'. This kanji honorific form has been explained above that besides read go, it may also be read o depending on the noun which follows.

The difference in word choice for noun referring to human is presented below.

3）もし遺児がなく，両親がその相続者である 場合は，母親はその3分の1を受ける。また もしかれに兄弟がある場合は，母親は6分 の1を受ける。 
Moshi iji ga naku, ryōshin ga sono sōzokusha de aru baai wa, hahaoya wa sono 3 bun no 1 o ukeru. Mata moshi kare ni kyōdai ga aru baai wa, hahaoya wa 6 bun no 10 ukeru.

'But if he had no children and the parents [alone] inherit from him, then for his mother is one third. And if he had brothers [or sisters], for his mother is one sixth.' (An- Nisâ'[4]:7)

In the data above, there are two nouns with honorific form when kanji 御 is in front of them, which are the words ryoushin (両親) 'parent' and kyoudai (兄弟) ‘brother/sister'. These words refer to human. In the Quran Japanese translation, the difference in language choice is clear. The words referring to human is not given with prefix kanji 御, unlike the words referring to Allah.

The following data are of the same verse (Verse 90) of surah An-Nisâ', showing the difference in the use of noun kokoro (心) 'heart' referring to Allah and human as His servant.

4）だが，あなたがたと盟約した民に仲間入り

した者, またはあなたがたとも自分の人び ととも戦わないと, 心に決めて, あなたの ところへやって来る者は別である。もしア ッラーの御心ならば, かれは, あなたがた よりもかれらを優勢になされ, あなたがた と戦うであろう。

Daga, anatagata to meiyakushita tami ni nakama irishita mono, mata wa anatagata to mo jibun no hitobito to mo tatakawanaito, kokoronikimete, anata no tokoro e yattekuru mono wabetsu de aru. Moshi Arrā no okokoronaraba, karewa, anatagata yori mo karera o yūsei ni nasare, anatagata to tatakau de arō. (An-Nisâ' [4]:90)

'Except for those who take refuge with a people between yourselves and whom is a treaty or those who come to you, their hearts strained at [the prospect of] fighting you or fighting their own people. And if Allah had willed, He could have given them power over you, and they would have fought you.'

There are two nouns of kokoro (心) 'heart'. The first kokoro refers to human's heart .... .their hearts strained at [the prospect of] fighting you or fighting their own people. This is human's heart, that is still strained at fighting you or their people. the next kokoro (心) is followed by kanji O- (御) serving as honorific marker for Allah, Moshi Arrā no okokoro nara ba, the word okokoro is followed by the word Arrā (Allah) showing the owner of the heart (okokoro).

The difference in the use of nouns above shows that communication in Islam shows high politeness. The honorific marker form in the nouns referring to Allah shows that we should, as Allah's servants, be humble and not arrogant, since the power over the whole world belongs only to Allah The Creator.

The data below show how the QuranJapanese translation specializes verbs referring to Allah. Allah is placed at the high position based on the use of the verbs. Allah's acts are placed at the position of those of The Almighty.

5）アッラーは, これらの者を御赦しになられ る。アッラーは全知にして英明な御方であ られる。

Arrawa, korera no mono o oyurushi ni narareru. Arrawazenchi ni shite eimeina mikata de arareru.

'It is those to whom Allah will turn in forgiveness, and Allah is ever Knowing and Wise.' (An-Nisa [4]: 17)

6) だが, 死に臨むまで悪行を続け，その時に なって「今悔い改めます。」と言う者, ま た不信心のまま死ぬ者の梅悟は御赦しにな られない。

Daga, shi ni nozomu made akugyo o tsuzuke, sonotoki ni natte "ima kuiaratamemasu" to iu mono, mata fushin gokoro no mama shinu mono no umesatoru wa oyurushi ni nararenai.

'But repentance is not [accepted] of those who [continue to] do evil deeds up until, when death comes to one of them, he says, "Indeed, I have repented now," or of those who die while they are disbelievers.' (An-Nisâ' [4]: 18)

There is Allah's the most forgiving character in the verse. In Japanese, the verb to forgive is shown with the word yurusu (赦す). The word yurusu is a common form verb, which means that the word, when expressed by an individual, has the meaning to forgive while containing no honorific sense towards the interlocutor. The word yurusumay refer to children, friends, brothers or sisters. In verses 17 and 18, the word yurusu experiences special changes aiming at exalting Allah by changing the verb showing act of Allah The Most Forgiving. In verse 17, the expression oyurushi ni narareru (御赦しになられる) shows 
that Allah forgives His servants who repent. The stem yurusu changes with prefix o-, changing the form yurusuintorenyoukei ${ }^{22}$ form of yurushi followed by ni narimasu, thus the respectful form of yurusu is oyurushi ni narimasu. The word narimasu in the data no 5 is changed again to honorific form of narareru, thus there are two changes to the honorific expression of Allah's act. This aims at showing that Allah's act is placed at a very high position. The same word choice is also used in the data no. 6. However, that in the data no. 6 is shown in negative form, that the word to forgive (oyurushi ni narareru) is changed to negative form oyurushi ni nararenai since in the verse, Allah does not forgive humans when they have not repent while death has come to them.

Language choice for Allah in Islamic communication in the Quran-Japanese translation may be observed in the following interaction between Allah and believers;

\section{7）アッラーはあなたがたの信仰を熟知される。}

Arrā wa anata gata no shinkō o jukuchi sareru.

'And Allah is most knowing about your faith.' (An- Nisâ' [4]:23)

The quote of verse 23 shows that Allah knows human's faith, the word know is addressed to Allah. Like verses referring to Allah's acts, this word is also specially treated as a language choice to honor Allah. This may be observed in the form sareru following the word shinkō o jukuchi.

It is different from language choice for human based on verb choice showing human's act, such as the word 'to believe' referring to human believing in Allah as in verse 19 .

1）あなたがた信仰する者よ，当人の意志に反 して，女を相続してはならない。

Anata gata shinkō suru mono yo tōnin no ishi ni hanshite,onna o sōzoku shite wa naranai.

'O you who have believed, it is not lawful for you to inherit women by compulsion.' (An- Nisâ' [4]:19)

There is an exclamation for the believers with expression; Anata gata shinkō suru mono yo ' $\mathrm{O}$ you who have believed!'. The verb believed in surah An-

${ }^{22}$ Renyoukei is a form of verb form in Japanese by removing suffix -masu in the word which follows, for example tabemasu which means 'to eat' as the form renyoukei of tabe. Similarly, for the words (Nomimasu 'to read' - nomi; kakimasu'to write'- kaki; yomimasu'to read' - yomi)
Nisa uses the word shinkō suru. The verb shinkō suru having the meaning to believe consists of the word shinko followed with a common form verb marker suru that is not used for verb marker for Allah. The verb marker suru is only used for human.

The language choice addressed to human is clear in an exclamation or order to human. An example of exclamation or order to human is given in the following verse.

2）出来るだけ仲良く，かの女らと暮しなさい。 あなたがたが, かの女らを嫌っても（忍耐 しなさい）。そのうち（嫌っている点）に アッラーからよいことを授かるであろう。

Dekiru dake nakayoku,kanojora to kurashinasai. Anatagata ga kanojora o kiratte mo (nintaishinasai). Sonouchi (kiratte iru ten) ni Arrākara yoikoto o sazukaru de arō.

'And live with them in kindness. For if you dislike them. Perhaps you dislike a thing and Allah makes therein much good.' (An- Nisâ' [4]: 19)

The verse instructs husbands to respect their wives by interacting with their wives in a correct way. Language choice to interact appropriately may be observed in the expression Dekiru dake nakayoku, kanojora to kurashinasai 'And live with them in kindness.' There is a command verb marker of shinasai. In Japanese, this command verb is a common form used for human. In verse 19, this command form is addressed to husbands for their wives. This shows a hablumminannâs relationship. Even if the husbands do not like their wives, the verse instructs them to be patient, as shown with the expression nintaishinasai. The expression nintaishinasai uses common language choice used by husbands to their wives bearing the meaning be patient (command to husband to be patient). The verse is concluded with Allah's promise to His patient servants.

\section{Conclusion}

Communication in Islam regulates language choice showing individual's politeness in communication both with fellow human and with Allah. Language choice is apparent in a servant's praying sentences. The Quran is guidelines for humans on performing Islamic communication. Besides by praying volume, praying sentences also show how language is addressed to human and Allah. The Quran-Japanese translation definitely 
shows language choice in each of its verses. Surah An-Nisâ' refers to women during the Prophet era, where women were treated badly by men that they were subordinated by men. More precisely, it discusses how jahiliyah era treated women, norms in interaction with wife, individual's right and obligations, violence, oppression, and forced subjection over women. The Quran-Japanese translation surah An-Nisâ' shows how language choices for Allah are different from language choice for husband against their wives and for wives themselves. Language choice is apparent in the use of nouns referring to Allah with kanji marker go/o (御) and verbs addressing Allah's act as shown with respectful sentences which in Japanese is called sonkeigo. These differences in language choice aim at educating humans not to be arrogant and to be humble since only Allah is the most high. The other aims is to be guidelines on Islamic communication, particularly in praying, in order to use polite language by exalting Allah and realize servant's love to Allah.

\section{References}

Arbi, Armawati, Komunikasi Intrapribadi "Integrasi Komunikasi Spiritual, Komunikasi Islam dan Komunikasi Lingkungan [The Integration of Spiritual, Islamic and Environmental Communication], Jakarta: Kencana, 2019.

Amarta, Joy, Kisah Teladan Perjuangan $25 \mathrm{Nabi}$ dan Rasul [The Inspiring Stories of 25 Prophets and Messengers], Yogyakarta: Cheklist, 2019

Daryanto, TeoriKomunikasi [Communication Theories], Malang: GunungSamudera, 2014

Dwiraharjo, Maryono, "Fungsi dan Bentuk Krama Dalam Masyarakat Tutur Jawa Studi Kasus di Kotamadya Surakarta (Krama Language Functions and Forms in Javanese language Use: A Case Study in Surakarta Municipality)", Dissertation, Yogyakarta:UGM, 1997.

Hefni, Harjani, Komunikasi Islam [Islamic Communication]. Jakarta: Kharisma Putra Utama, 2017 , Komunikasi Islam, Jakarta: Prenada Media, 2017

J.B Pride and J Holmes.Sociolinguistics, England: Penguin, 1972

Kabaya , Hiroshi. et al, Keigo Hyougen, Tokyo:Taishuukan, 2009

Kaneko, Hiroyuki, Nihongo Keigo Toreeningu. Tokyo: PT Ask, 2004
Kasheh, Natalie, Hadrami Awakening: Kebangkitan Hadrami di Indonesia ([Hadrami A wakiening in Indonesia), Jakarta: Akbar Media Eka Sarana, 2007.

Kikuchi, Yasuto, Keigo Nyuumon.Tokyo: Maruzen, 1997

Mita, Umar, Sei Kuruaan, Tokyo: Nihon Muslim Kyoukai, 2012

Moleong, Lexy J, Metodologi Penelitian Kualitatif [Qualitative Research Methodology], Bandung: PT Remaja Rosdakarya, 2001

Purwo, Bambang Kaswanti "Tingkat Tutur Bahasa Jawa: Tata BahasadanPragmatik (Javanese Language Use Levels: Language Patterns and Pragmatics)", Paper in Congress of Javanese Language I, Semarang, 1991.

R Fashold, The Sociolinguistics of Society. Oxford: Basil Blackwell, 1984

Ruslan, "Language Variation Analysis of Expressions of Al-Quran Word Wife", Research on Humanities and Social Sciences: vol.4, no.11, 2014.

Rahayu, Ely Triasih, "Sonkeigo Expressions in Japanese Translation of the Quran." MADANIA: JURNAL KAJIAN KEISLAMAN, vol. 21.no. 2, 2017. , Sistem dan Fungsi Tingkat Tutur Bahasa Jepang dalam Domain Perkantoran (Japanese Language Use Systems and Functions in Office Domains), Dissertation, Universitas Sebelas Maret, 2013.

, Comparison of Honorific Language in Javanese and Japanese Speech Community. International Journal on Studies in English Language and Literature (IJSELL). Volume 2, Issue 7, July 2014, PP 140-146.ARC:India

Sugiyono, Metodologi Penelitian Kualitaif, Kuantitatif dan Kombinasi [Qualitative, Quantitative, and Mixed Research Methodology], Bandung: Alfabeta, 2016

Suwito, "Berbahasa dalam Situasi Diglosik: "Kajian tentang Pemilihan dan Pemilahan Bahasa dalam Masyarakat Tutur Jawa di Tiga Kelurahan Kotamadya Surakarta (Using Language in Diglossic Situations : A study on Language Selections in Javanese Language Use)", Dissertation, Jakarta: UI, 1987.

Usmani, Rasm, Al-Qur'an Tafsir Perkata [Quran and its Interpretations Say], Bandung: Cordoba, 2018

Warsiman, Sosiolinguistik"TeoridanAplikasidala mpembelajaran" [Sociolinguistics "Theories of Learning and its Applications"]. Malang: UniversitasBrawijaya Press, 2014. 